\title{
THE HISTORICAL ORDER OF MALAYSIAN SOCIOCULTURE IN INTERLOK
}

\author{
Mohd. Hanafi Ibrahim
}

hanafi@dbp.gov.my

Dewan Bahasa dan Pustaka

\begin{abstract}
Interlok is a literary work with a specific theme that resulted from a contest and it proposes the subject of national integration at its core to fulfil the aspirations and the development of the then newly independent Malaysia. The historical framework is used as an instrument for discourse purposes in addressing socio-cultural and humanitarian issues related to the solidarity and development of the Malaysian nation. Therefore, this novel may be categorised as a socio-historical novel and not purely a historical novel. Interlok provides the opportunity to the reader to explore the author's profound meaning in introducing the subject of solidarity as the foundation of the development of the Malaysian nation. The difference in values among the races has to be narrowed whereas the quality or the advantage possessed by each of the respective races has to be assembled to obtain maximum benefit.
\end{abstract}


Keywords: Interlok, historicising fiction, fictionalising history, solidarity, socio-cultural, socio-historical

\section{INTRODUCTION}

Interlok, the work of National Laureate Abdullah Hussain, won the consolation prize of RM1,000 in the Novel Writing Competition marking Malaysia's tenth year of independence. The competition was launched in December 1967 and ended in June 1968. In this competition, the judging panel recommended none of the works as first prize or second prize winners. However, Arena Wati's Sandera was placed third, whereas other novels were given consolation prizes. They were Badan Bertuah (The Lucky One) by Ismail Al-Falah, Pulanglah Perantau (Please Return, Wayfarer) by Aziz Jahpin, Merpati Putih Terbang Lagi (The White Dove Flies Again) by Khadijah Hashim and Interlok. These novels fulfilled the rules and regulations of the competition, one of which should be an original writing in Bahasa Melayu. The theme had to be based on the struggle for independence, the development of the country and life in Malaysia.

The meaning of the struggle for independence should not be limited to the struggle after war. Here, the meaning of development is the upheaval of efforts in developing Malaysia as a result of independence that involved changes in the viewpoints and lifestyle of Malaysians-spiritually and physically. ${ }^{1}$

In their arguments, the judging panel stated several weaknesses in terms of how the stories were conceived based on the given theme, weaknesses in the plots, language use, characters and style. Nevertheless, they admitted the submitted works possessed "... an awareness and the writers' effort reflected the upheaval in society, the need to amend weaknesses in society and cultivate new values, to take pride in the history of the nation's struggle and social critiques which were also deemed constructive".

In light of that, this article will utilize the historical and socio-cultural perspectives to show how far the novel Interlok ${ }^{3}$ was created in accordance with the theme of independence, the development and the life of people in Malaya within the timeframe and milieu the text was based upon. 


\section{Historicising Interlok}

Interlok was produced with the purpose of instilling the idealism of the author, Abdullah Hussain, in "uniting the many races of this nation, through familiarising oneself with the historical experience of one's own race in Malaya" (Abdullah Hussain. Berita Harian, 20 December 2010). When the author conveyed his intensity to create solidarity by understanding the origin of each race in Malaya in the novel Interlok, the text was considered a work of fiction that was produced based on the reality or the history of the society during the time period of the text.

When associating a literary text with history, an issue arises as to the authenticity of Interlok as a fictional work, which was written through the imagination of its author in presenting his idealism or his thoughts particularly on issues of solidarity by familiarising oneself with the history of each individual race in Malaya. Writing an imaginative fiction is worlds apart from writing on history, which is factual.

Umar Junus, in his study on the connection between fiction and history, presented two phrases to clarify the connection despite the varying implications, which are the "historicisation of a fiction" or the "fictionalising of a piece of reality or history". The reality of history will present the doer, date and the true historical event. However, the phrase "fictionalising history", is conducted by concealing the reality of history through changing the names of historical figures and events, relating a fictive story and incorporating fictitious figures into a story. ${ }^{4}$

Both phrases give alternative consequences; through historicising fiction, the text will be read as a product of the reality of history and hence, decreases its value as fiction. Therefore, the text is said to have failed as an imaginative fiction and is only a piece of work on the reality of history. ${ }^{5} \mathrm{In}$ fictionalising history, a piece of text is seen as a work of pure fiction as it conceals or dispels traces of the reality of history. Nevertheless, when the text is produced using elements of language that possess signs and omens, it will be read speculatively ${ }^{6}$ until eventually the reality of history which is concealed or disguised will be revealed when it is connected to the true reality of history. Therefore, it means that a particular text that fictionalises history also brings the reality of history into the text. Both methods use reality in the text. The difference is through the method; in historicising fiction, its input on reality is carried out in the open, whereas in fictionalising history, the reality of history is done in a hidden or disguised manner. 
If the background structure is carefully examined, this novel presents several elements of history which became the backdrop of the formation of an independent nation, Malaya. A number of facts and important events are included. Firstly, British colonial rule in Malaya, particularly British domination in the Straits Settlements such as Singapore and Penang. Secondly, the history of the economic development of Malaya which was based on capital markets and paid workforce in the farming and mining sectors mainly in the Federated Malay states. Thirdly, the fact of the influx of immigrants from Southern China and Southern India who became the workforce which formed the pluralistic society of Malaya. This is followed by the emergence of political awareness among the Malays that produced movements that opposed the Malayan Union as well as the formation of political organisations among the Chinese and Indians to safeguard the interests of their own race. These events became the huge frame of history as the background milieu and the socio-cultural, economic and political elements in Interlok. Therefore, this novel is not precisely a historical novel but a fiction that fictionalises history and removes historical facts without the insertion of real characters, actual dates and true historical events.

This novel also presents the development of infrastructure such as education, particularly among the Chinese characters who strove to establish vernacular schools to retain the elements of culture and racial identity inherited from their ancestral land. In addition, the colonisation of the Japanese fascists, the state of emergency, the infiltration of communist ideology, and consequently the independence of Malaya in 1957 became the background of the text. The inclusion of these historical events is analogous to fulfil the "historicising of fiction" as each event was connected to the reality of true events in Malaysian history. Nevertheless, the question arises as to whether this novel could be precisely classified as a history novel, which according to Coster's view, ${ }^{7}$ is solely based on the presence of true historical events in the text, whereas, if we carefully examine each event in the novel, there were no accurate details of historical facts in terms of the dates of the events and real figures that appeared in historicising the history of Malaya. Those historical events were only present as a background of the socio-cultural milieu of the society in that period of time which provided the basis of the text. The historical events were merely benefited through fictitious imagination to describe human relationships and humanity in a socio-cultural system in a country which was soon to be formed. 
Based on the notes in Interlok, the background of the story was culminated in a five-decade period, between the years 1910 and 1957. These dated notes were based on the time the character Maniam who originated from the west coast of Southern India migrated to Malaya on a ship from the port city of Nagapatnam ${ }^{8}$ in July $1910^{9}$ and embarked in Penang to find job opportunities that helped to reverse the fate of his impoverished wife and family living in India. In Interlok, migration among workers from India to Malaya during the colonial era of the early 20th century were carried out in two methods, the first being the Kangani ${ }^{10}$ system and the other as freelance ${ }^{11}$ workers. Through the Kangani system, the recruitment of workers was executed in a systematic and organised manner. Freelance workers who arrived in Malaya on their own expense were free to work anywhere they wanted, as was the case with Maniam. Indian workers brought in under the Kangani system worked in estates or farms or on construction sites. ${ }^{12}$ Up until Interlok's point of time in1957, the text was all based on preparations by the multi-racial society to visit Kuala Lumpur to celebrate the declaration of independence of Malaya on 31st August 1957..$^{13}$

At that time, the novel also presents the history of the development of a nation based on the capital market economy by the British colonial government who were actively developing the farming and mining sectors. In Interlok, this farming sector was located in Changkat Lima and Changkat Janggus (pp. 223-21). The location for the mining activity was in Kuala Lukut (p. 121). The rapid growth of the capital market economy required many workers, thus the arrival of labourers from China and India. These migrants eventually spread their wings throughout Malaya, dominating the Malayan economy in various fields.

In Interlok, the advance of the Chinese to Malaya was seen through the eyes of Kim Lock and his son, Cing Huat, who landed in Singapore along with other workers from China. They made their way through Johor, Malacca, Negeri Sembilan and finally settled in Simpang Empat, Penang. Both these characters were determined to strive hard by taking up many jobs such as loading goods at the docks, as rickshaw pedallers and shop assistants, mining and finally becoming successful shop owners.

Also included were events resulting from the colonisation of Japanese fascists who tyrannised the people and brought misery to all races in Malaya such as to the families of Cing Huat, Mak Limah and also Maniam. The Japanese colonisation of Malaya also spurred the escalation of the national spirit among the Malays to acquire the country's freedom and independence when the British re-colonised 
Malaya after Japan's defeat in the Second World War. The character of Cikgu Lazim triggered an awareness movement among the Malays particularly in going against the Malayan Union to defend the rights of the Malays and the sovereignty of the Malay rulers. ${ }^{14}$ The state of emergency, the influence of communism ${ }^{15}$ and also the background of the establishment of Chinese and Indian political parties to safeguard the interests of their own race in Malaya ${ }^{16}$ along with the facts on independence were also included in Interlok to reveal the setting of the text. ${ }^{17}$

Based on discussions, it is revealed that the author only included the historical events as part of the grand frame which provided the socio-cultural experience in Interlok. Nevertheless, a literary work that uses historical events as a time period milieu is not intended to document data, facts and historical events precisely like a work of fiction, but to apply the thinking that the author is trying to present to suit the purpose of the production of the work based on the spirit of the era in which it was produced.

When the novel was written to answer the spirit of the competition in commemorating ten years of independence, the writer had the freedom to interpret and present the message of independence in whatever framework including the usage of historical elements to analyse issues in the construction of the Malaysian race. Historical events were used as social and psychological background on the subject of human relations and humanity; the characters of a country on the verge of independence, consequently planning to generate development opportunities that brought collective prosperity towards a better life on the basis of integration and consensus. Based on the combination of historical and socio-cultural materials in the fictitious imaginative text, this novel could be classified as a piece of socio-historical work.

\section{Interlok and the Socio-cultural Order}

Based on the discussion above, Interlok uses the historical, social, economical and political settings in Malaya during the colonisation period of around the early 20th century until Independence Day on 31st August 1957. In the region of the milieu and the background of the era, this novel presents the historical origins of the three major races of Malaya, namely the Malays, Chinese and Indians. The Malays were the original settlers, whereas the Indians and Chinese were the migrant workforce coming from India and China. Based on the time period, it also presents the push factors that spurred the exodus of immigrants from the lands of origin and the pull factors to Malaya up to the point where it was inundated with immigrants. 


\section{Social Perspective}

Interlok portrays life in Malaya in the early 20th century which was entering the era of modernisation through the capital market economy with the opening of rubber plantations and tin mines in the Malay Peninsula and the bustling business sector, particularly in the metropolitan cities of the Straits Settlements such as Singapore and Penang. This novel portrays elements of progress that were sporadic, with accelerated economic growth in the urban areas while the rural areas in the outskirts remained underdeveloped. The Chinese flocked to cities or towns such as Singapore, Penang, Malacca and Simpang Empat whereas the Indians worked in rubber plantations. The Malays, as the original settlers of Malaya, were more concentrated in traditional agricultural activities for subsistence.

The structuring of race composition based on their location in urban or rural areas had caused racial segregation. Each race was also separated by various occupations. For instance, the Chinese flocked the cities which were equipped with economic and social infrastructure, hence, making economic opportunities easily accessible to them. Unlike the Chinese, the Indians and the Malays were settled mainly in the rural areas.

The experiences of all three races during that time can be categorised into three chapters; the Seman family can be found in Book One (Chapter One), the Cing Huat family in Book Two, and the Maniam family in Book Three. In Book One, the life of a Malay family in the rural community of Kampung Nyiur Condong was presented. The family comprised of Pak Musa, Mak Limah and their son, Seman. Among the rural community, Pak Musa's family could be classified as well off in terms of material wealth. Nevertheless, the wealth that they owned in the form of livestock, orchard, land and house did not really belong to them but to Cing Huat, the grocer in the town of Simpang Empat. As original settlers of Malaya, the Malays lived in a prosperous country with the source of wealth coming from land crops. Ironically, one may work hard but if not educated would cause his possessions to change hands. Pak Musa's penchant for borrowing money and taking loans by putting up his possessions as collateral at Cing Huat's shop, eventually brought his family to destitution when they were left with only the clothes on their backs following the pawning of their possessions as a result of inability to pay their debts.

A big issue in that era was the failure of the Malays to generate and obtain economic opportunities caused by their lax attitude and backward thinking 
of retaining traditional elements that were disadvantageous and rejecting the profitable advances of the era. In this novel, for instance, Seman was not given formal education suited to the needs of his time although it was strongly recommended by the headmaster. On the contrary, he was given religious education so that it was sufficient to fulfil his own needs and enable him to recite the Qur'an. With that type of attitude, the Malays were unable to access the latest economic opportunities available. The Malays continued to lag behind in poverty in their own land. A critique may be directed at the Malays who easily felt comfortable, assured and safe among their own community, and eventually became preoccupied and forgetful, placing them at the losing end.

The attitude of this Malay family was unlike that of the Cing Huat family in Book Two (Chapter Two). Cing Huat's migration to Singapore and Malaya accompanied by his father when he was a child was motivated by the purpose of seeking a better life for his family that was living a difficult life back in his homeland. Poverty persisted due to the farmlands being subjected to natural disasters such as floods and the attack of locusts which subsequently made them look for other alternatives for survival. The only opportunity that existed was by migrating after witnessing other people successfully accumulating wealth in that way. The difficulties faced during the voyage and the hardship faced in seeking a livelihood in this new land motivated both Kim Hock and his son Cing Huat to work harder, taking up any jobs as long as they were fruitful. Success in life became theirs after their involvement in business and accumulating great amounts of wealth, including those previously owned by the Malays.

In Book Three which revolves around the Maniam family, the issue of social class and ancestry as a result of the caste system in the Indian community was presented. Through this system, the basic rights and values of humanity were neglected when those of a lower caste were frequently rejected by society. Maniam only owned an old cow and the house that he lived in with his wife. Life was difficult until he made the decision to migrate to Malaya as a freelance worker. He joined a number of workers from India who were brought into Malaya through the Kangani system. As a freelance worker, jobs were not so secure compared to those under the Kangani system. Maniam took on many jobs and later resided in Changkat Janggus working on a rubber plantation owned by an English master.

The author takes readers through the origins of these characters and the problems that pushed these people out of their homelands by making the 
purpose of obtaining economic interests in Malaya a priority in their lives. The influx of immigrants formed a pluralistic society in Malaya in terms of origin, race, culture and religion, each living separately in different locations and doing different jobs, leading to racial polarisation. This continued until the point where the three races incidentally came together, having failed to get to know each race's innermost nature, which led to misinterpretation and strong racial sentiments as experienced by Cing Huat towards the Malays whom he considered impolite. Cing Huat's purpose in pursuing life in Malaya was solely to obtain wealth and he did not consider the new land as his permanent residence. However, his principles changed when he discovered the ties he had with his homeland had been severed, more so after the birth of his sons, Yew Seng and Poh Eng in Malaya. They never knew their homeland and had become one with the air and life in pluralistic Malaya and thus, considered it their homeland.

Beginning from the above historical background and milieu, the author used his creativity to present his collection of thoughts to unite the people of Malaya which comprised of the three largest races; the Malays, the Chinese and the Indians in Chapter Four of Interlok. The calamities faced by each family brought the relationship among the races close together. Seman and his mother, who had to move out of their village as their home and land were pawned to Cing Huat, were assisted by Maniam who helped them obtain jobs at the Changkat Janggus rubber plantation. Musa, Seman's father, once helped Maniam, when he was assaulted by strangers after his eviction from Changkat Janggus farm. During the Japanese occupation, Seman and his mother protected Poh Eng, Cing Huat's son. Ramakrishnan, Maniam's son saved Mak Limah and Poh Eng from being captured by the Japanese. These examples of coincidences produced racial unity and the characters eventually took on collective roles in gaining independence for Malaya.

\section{Economic Perspective}

Under the British rule, economic activities in Singapore and Penang expanded particularly in trading. In Malaya, economic activities on a macro scale were also developing when tin mining activities started in places like Lukut and Taiping. The text also highlights the development in the farming sector when estates and rubber plantations were opened, among them the farm of Changkat Lima and Changkat Janggus. In the early 20th century, in the era of rapid economic growth, the economy of Malaya was apparently generated 
through the capitalist economy system based on the capital market. Growth on a macro level in the economic sector was spurred through the opening of rubber plantations, mines and entry-ports that handled import-export activities and the usage of hired labourers. In Interlok, rapid growth of the economy and job opportunities was evident in big cities such as Singapore, Penang and Malacca under the administration of the Straits Settlement. Rapid economic growth, job opportunities and the opportunity to be involved in various economic activities were the pull factors for the influx of immigrants, particularly those from China and India. Labourers from India, for instance, were brought to Malaya in an organised manner through the Kangani system (p. 181), a workforce recruitment system in which they became farmhands in Malaya.

Interlok described how labourers from China were also admitted in an organised manner by employment agents such as Paman Kok Leng who brought them in through the kongsi house system (p. 99). ${ }^{18}$ Through the system, workers from China were gathered in a kongsi house in Singapore until they obtained jobs and were moved to Muar, Malacca and Penang (refer to the migration of Kim Hock and his son Cing Huat until they resided in Simpang Empat). There were also workers who migrated on their own free will, for example Maniam, who boarded a ship departing from the port of Nagapatnam with other labourers coming to Malaya through the Kangani system.

These characters were employed in various types of jobs available and new jobs were later introduced as a result of the economic growth, among them port coolies, restaurant workers, road labourers, teachers, policemen and so on. This novel also indirectly sketched the pattern of movement among immigrants from China and India to all parts of Singapore and Malaya, not only by being port coolies, road construction labourers and rickshaw pedallers, but also dominating the trade sector, "There were indo kuai who opened coffee shops or textile shops like most people who come from Tung San." However, the Malays were seen as not being interested in business, "None of the Malays opened any shops, none of them became coolies. Most of them worked with the government. Some were the drivers of the White Devil” (p. 100).

\section{Political Perspective}

Discussions in the earlier sections point out how Interlok used the political background of Malaya in the span of five decades. During that period, Malaya in the early 20th century was under British colonisation as data found in 
the text portrayed the English authorities as the "master" that dominated Singapore and Malaya, "This country is theirs, but the white devil is the master" (1971:95). British colonisation brought major changes in the social and economic sectors of Malaya. Indirectly, British colonisation had changed the composition of the residents of Malaya into a more pluralistic society. The pluralistic characteristics were then shaped into fragmented conditions based on the patterns of settlement and economic activities, eventually resulting in a gap in racial relations.

During the rule of the Japanese fascists and the state of emergency, the life of all races became difficult because of the war and the clashes in ideology until it eventually took its toll on the people's quality of life. The resistance of the Malays towards the establishment of the Malayan Union directly precipitated the growth of the national spirit and eventually, with the cooperation of all races, the people celebrated the country's independence. The celebration by all three major races went on for three days and three nights (pp. 337-38).

Interlok also presented issues related to the establishment of individual organisations and political bodies whose purpose was to safeguard the interests of each race towards collective efforts in playing their role in eventually obtaining independence through tolerance of each other. This novel portrayed how the immigrants, who at the beginning came to Malaya to work and seek a better life and later planned to return to their homeland, changed their principles after having enjoyed a comfortable life in Malaya. To sustain this ownership they strived to obtain citizenship of Malaya.

In this novel, historical events were used as fragments and frames, merely as the socio-cultural background of space and milieu not precisely stated through historical facts such as dates, events and historical figures. It was more of a statement of socio-cultural history of the three major races about their origins, cultures, purposes and aims in the beginning to build a life in Malaya. This novel is more inclined towards expressing the aspirations of the author to make full use of the novel as a piece of work that inspired racial unity and integration in building a newly independent Malaysia. The socio-cultural aspect related to all aspects of life of the three races in Malaysia in terms of economic, social and political interests is more apparent if compared to the historical aspect. 


\section{Conclusion}

Interlok is a literary work that only makes use of history as a socio-cultural milieu to relay the humanitarian thinking of the author in establishing solidarity among the races. Therefore, dates and historical facts were not emphasised in the novel. Through careful and rational reading of this novel, it is found that Interlok places importance on the subject of unity among the three major races of Malaya. This is evident from the narrative strategy of the author who reorganised the segmentation of space and the difference of opportunities among the races implicated by the colonial economic policy and administrative system. The immigrant workforce was portrayed as living in segregation and exclusivity within the community of their race. The author then connected these three races in some form of direct and indirect cultural encounters through economic and work activities.

This novel accentuates the sincerity in the purpose of its production, which is to construct a united Malaysian race to plan the development agenda and the concordance of the country. The diversity of culture among races was illustrated by the mutual respect of the traditions and cultures of each race. The tolerance of the Malays as the original settlers of Malaya towards the immigrant workforce by providing them with the opportunity to reside in Malaya and the opportunity to lead a better life should be appreciated. This opportunity was freely given unlike the situations in their homelands which were fraught with natural calamities and the gap in human relations caused by serious issues in the social strata. In Malaya, basic rights and equal living opportunities to generate economic opportunities are emphasised in Interlok.

Misreading the text and the context of this novel could revive rash sentiments that may cause prejudicial attitudes in society. For instance, the caste issue had been sensationalised with a sensitive connotation elsewhere whereas in Interlok, the caste issue referred to the practice of another country and did not happen in Malaya. Humanitarian values and human rights in this novel were at the highest level when everyone, regardless of their origin and ancestry, had the same standard of living. Each and every race possessed the same space and opportunity to achieve success based on one's effort and capability, regardless of one's rank and ancestry. This was admitted by Maniam, when he felt happy living in this country because for the first time in his life he felt human just like everybody else (pp. 176-77). 
The text Interlok fulfils the purpose of establishing unity among the various races of Malaysia. The recipe to establish unity is by mutually understanding the historical foundation of the formation of the Malaysian race. Interlok could be utilised to instil elements of patriotism and citizenship, by emphasising the spirit of love and loyalty to the country. This novel should be benefited to cultivate, in future generations, a balanced and harmonious living in terms of intellectual, emotional and physical abilities.

A literary text can become an instrument for students to master learning skills in aesthetic values which focuses on their ability to master the aspects, beauty and intricacy of language, emphasising on the appreciation of a beautiful piece of work through the expression of feelings and a sensible trace of appreciation. In this matter, society, teachers and parents should collectively become educators in shaping the younger generation with healthy minds, assisting them in reading literary texts and providing guidance for its meaning; not hastily propelling emotions and sentiments out of proportion by politicising the literary texts.

The future of a newly formed nation in this novel was actually borne by the younger generation who determined its survival and the meaning of independence that brought collective well-being and prosperity. Moreover, the signs of awareness and the rise of the younger generations in this novel were represented by the third generation in Pak Musa's family, seen in the character of his son, Seman, in Cing Huat's family in his sons Yew Seng and Poh Eng, and in the Maniam family in his son Ramakrishnan. They were among the new generations born in Malaya. The new generation of the Chinese characters, Yew Seng and Poh Eng, who never knew their ancestral land, were thankful for the new land they were born in and appreciated the characteristics of a pluralistic society they lived in, particularly of the Malays as the original citizens. The Malay race was seen as the natives who were generous and willing to surrender some of their rights to those who were originally immigrants. The same went for Seman, Pak Musa's son, who rose with renewed resolve in an effort to create a better future, to avoid the unfortunate events that had befell his father who was oppressed through the system of land and house collateral resulting in their possessions being pawned. The younger Malays possessed the vision to improve the standards of living of Malays through education and political awareness. Meanwhile, Ramakrishnan, Maniam's son, was the third generation of the Perumal family, acting as a saviour for all races during a difficult time, bringing a message to mutually safeguard the interests of all races. This 
was the hope harboured by the author towards the potential of the younger generation to learn from history; not to become too absorbed in oneself and one's race, but be mutually respectful and helpful to create a brighter future for a newly independent nation. Symbolically, this racial unity was apparent through the contribution of the people of all races; the Malays, Chinese and Indians in providing a prosthetic leg to Yew Seng who was injured (p. 340). Yew Seng's decision to accept this contribution from the different races and not from his father alone who could well afford to do so based on his economic strength, was a choice in celebration of the spirit of co-operation and tolerance among all races. This is the recipe for the construction of a solid country according to the perspectives of Interlok.

\section{Notes}

1 Report by the competition's panel of judges, Documentation File, Dewan Bahasa dan Pustaka.

2 Documentation File, Malay Documentation Centre, Dewan Bahasa dan Pustaka.

3 Abdullah Hussain, 1971. Interlok, Kuala Lumpur: Dewan Bahasa dan Pustaka.

$4 \quad$ Umar Junus, 1989. Fiksyen dan Sejarah Suatu Dialog (The Fiction and History of a Dialogue). Kuala Lumpur: Dewan Bahasa dan Pustaka, pp. 113-16.

5 Umar Junus, 1989. pp. 113-16.

6 Umar Junus, 1989, pp. 117-21.

7 Zeti Aktar Jaffar (ed.), 2008. Abdullah Hussain dalam Esei dan Kritikan (Abdullah Hussain in Essay and Critiques). Kuala Lumpur: Dewan Bahasa dan Pustaka.

8 Asaratnam, S., 1979. Indian in Malaya and Singapore (ed. revised 1970). Kuala Lumpur: Oxford University Press. Note the name of the port that managed most of the workforce from India to Malaya as Nagapatnam.

9 Abdullah Hussain, 1971. Interlok, Kuala Lumpur: Dewan Bahasa dan Pustaka, p. 169.

10 Leader, supervisor or monitor who was tasked with “... a tyndal or Kangani to India, giving him an advance to pay expenses, and the man returns with coolies and in due course repays the advances. By what agreement the coolies are bound to the kangani, who has to recover their passage money from them, is not known, the employer refraining from any interference in details" Jackson, 1971, p.101 in (Rahimah Abdul Aziz, 2000). 
11 There were also other methods in recruitment of workers. One of them was through the Contract System that required workers to work for a period of five years and this contract could be renewed for another five years. Refer to Rahimah Abdul Aziz.

12 Rahimah Abdul Aziz, 2000. Pembaratan Pemerintahan Johor (Westernization of Johor Rule) (1800-1945). Kuala Lumpur: Dewan Bahasa dan Pustaka, p. 208.

13 Interlok, pp. 337-38.

14 Abdullah Hussain, 1971, pp. 316-19.

15 Abdullah Hussain, 1971, pp. 320-22.

16 Abdullah Hussain, 1971, pp. 323-24.

17 Abdullah Hussain, 1971, pp. 327-40.

18 The number of foreign labourers in the Federated Malay States in Malaya who worked in the estates, tin mines and factories were 116046 Indians and 90740 Chinese, whereas there were 1156 Malay and 3194 Javanese labourers. Please refer to the enumeration in the Annual Report of the Labour Department Malaya for the Year 1938. Details are contained in Abdul Latiff Abu Bakar, 1984. Abdul Rahim Kajai Wartawan dan Sasterawan Melayu. Kuala Lumpur: Dewan Bahasa dan Pustaka, p. 240.

\section{References}

Abdullah Hussain, 1971. Interlok. Kuala Lumpur: Dewan Bahasa dan Pustaka.

Abdul LatiffAbu Bakar, 1984. Abdul Rahim Kajai Wartawan dan Sasterawan Melayu. Kuala Lumpur: Dewan Bahasa dan Pustaka.

Asaratnam, S., 1979. Indian in Malaya and Singapore. Revised Edition. Kuala Lumpur: Oxford University Press.

Report of Competition Panel of Judges, Documentation File, Dewan Bahasa dan Pustaka.

Rahimah Abdul Aziz, 2000. Pembaratan Pemerintahan Johor (1800-1945). Kuala Lumpur: Dewan Bahasa dan Pustaka.

Umar Junus, 1989. Fiksyen dan Sejarah: Suatu Dialog. Kuala Lumpur: Dewan Bahasa dan Pustaka,

Zeti Aktar Jaffar (ed.), 2008. Abdullah Hussain dalam Esei dan Kritikan. Kuala Lumpur: Dewan Bahasa dan Pustaka.

(Translated by Noor Khairiyati Ali) 